\title{
Frampeik frå ei faren tid
} \author{
skapsbasert praksis.

\section{Elling Ulvestad} \\ elling.ulvestad@helse-bergen.no \\ Mikrobiologisk avdeling \\ Haukeland universitetssjukehus \\ 5021 Bergen \\ og \\ Gades institutt \\ Universitetet i Bergen
}

Det at helsestyresmaktene i aukande grad ser behov for å regulere medisinsk praksis gjennom retningsliner kan sjåast som eit symptom på at praktikaren i mange høve manglar eit handlingsrettleiande medisinskteoretisk rammeverk å stø seg til. Med utganspunkt i G.W.F. Hegels (1770-1831) og Charles Darwins (1809-1882) skrifter søkjer eg i denne artikkelen å vise at medisinen gjennom å ta opp i seg åndsog naturhistorisk kunnskap vil kunne utvikle både eit naudsynt teoretisk fundament og eit nytt innhald til det etter kvart utvatna omgrepet kunn-

Med biletet Kvar kjem vi frå? Kva er vi? Kvar går vi? ønskte Paul Gauguin (1848-1903) å uttrykkje svar på nokre spørsmål mennesket har grunna over til alle tider (fig 1). Dei gamle greske filosofane, med Sokrates i spissen, meinte at svara var å finne i det einskilde mennesket sjølv, medan dei store verdsreligionane søkte svar i meir transcendente sfærar. Gauguin formulerte ikkje svara med ord, men vurdert ut frå biletmotivet meinte han truleg at løysinga på spørsmåla finst $\mathrm{i}$ den einskilde sin biografi.

Mykje erfaring frå ulike menneske si livsverd tyder på at Gauguin hadde belegg for løysingsforslaget. For dersom ein vil forstå kven ein er og kvar ein skal, kan det på ferda gjennom livet vere nyttig å sjå seg attende. Den som har sett garn frå ein færing veit kor nyttig det er å ta seg ut eit méd over og bak akterstamnen for å kunne halde stø kurs framover.

I denne artikkelen utvidar eg Gauguins biografiske perspektiv, som også er den medisinske vitskapen sin ståstad, med eit ånds- og naturhistorisk perspektiv. Eg argumenterer for at sameining av dei tre perspektiva er naudsynt dersom ein skal kunne gje adekvate svar på Gauguins spørsmål (1).

\section{Medvit frå ei faren tid}

Sidan Gauguins spørsmål er av eksistensiell form, har dei naturleg nok fått mykje merk- semd. Eit vesentleg bidrag til forklårande svar stod Hegel for (2). I motsetnad til den biografiske orienteringa meinte han at mennesket er eit resultat, ikkje berre av soga til den einskilde, men av heile menneskeætta si soge. Det einskilde mennesket vart hjå honom å sjå som eit førebels resultat av menneskeånda si danningsreise gjennom tida. Med dette kunne Hegel gje svar på både kvar vi kjem ifrå og kva vi er. Men han hadde høgare ambisjonar enn som så han ynskte også å fortelje retninga på ferda gjennom soga. Og langs denne leia såg han på det einskilde mennesket som ei brikke. Den verkelege aktøren var for honom menneskeånda som strevde med å kome til seg sjølv. Når ho endeleg nådde målet, når alle motsetnader var oppheva og omgrepa harmonisert med verda, då meinte Hegel at mennesket si danningssoge ville vere over. Han nytta uttrykket «fornuftas list» om denne danningssoga; menneska handla individuelt og lokalt rasjonelt for å realisere sine mål, men bak ryggen deira opererte fornufta med kan hende heilt andre mål for auge.

Charles Darwin var empirikar og såleis ingen intellektuell arving av Hegel. Men som Hegel var han overtydd om at historia var ei viktig kjelde for svar på gåta om menneskenaturen. I 1859 publiserte han Om artane sitt opphav (3) og viste der for fyrste gong korleis naturlege mekanismar kan forklare framveksten av livet på Jorda. Med hegelsk terminologi vil prosessen, som Darwin kalla naturleg seleksjon, kunne omtalast som «naturens list».

Prinsippet for naturleg seleksjon byggjer på tre premiss: Innan alle artar er det ein utstrakt variasjon mellom individa, variasjonen er arveleg og individa får meir

\section{Menneskets opphav}

avkom enn omgjevnaden kan bere, noko som igjen fører til kamp om ressursane. Ut frå desse føresetnadane postulerte Darwin at dei best skikka variantane innan eit gjeve miljø vil overleve og reprodusere seg i større grad enn andre variantar. Det vil igjen føre til at dei gode eigenskapane som individa ber på, vil vinne fram. Denne prosessen har over tid ført til evolusjon av alle dei komplekse livsformene som vi ser rundt oss i dag.

I Om artane sitt opphav la Darwin fram ein teori som i dag er ålment akseptert som den beste vitskapleg baserte forklåringa på livet si utvikling. I ei seinare bok, Menneskets avstamming (1871) (4), tek han utgangspunkt $\mathrm{i}$ at også mennesket stammar frå tidlegare skapnadar, og at seleksjon var eit vesentleg moment $i$ den historiske prosessen som førte fram til notidsmennesket. Særleg var han oppteken av å vise at mennesket sine høgare mentale eigenskapar, til dømes intellekt, moral og estetisk sans, ikkje var eineståande for mennesket. Han dokumenterte med ei rad eksempel at eigenskapane hadde parallellar i dyreriket og at dei menneskelege trekka såleis var å sjå på som utsprungne av same kjelda som dyra sine. Konklusjonen vart dermed at forskjellen mellom dyr og menneske, som utvilsamt er stor, er ein forskjell i grad ikkje i essens.

Til tross for likskapane, Darwin meinte at den naturlege seleksjonen verkar annleis på det siviliserte mennesket enn på fortidsmennesket og andre dyr. Han peikte mellom anna på at det kulturelle mennesket freistar å ta vare på dei svakare artsfellane. Mellom anna har samfunnet instituert eit helsevesen som tek seg av dei sjuke individa, og det søkjer å førebyggje sjukdom gjennom vaksinasjon. Som den oppmerksame teoretikaren han var, forstod han at slike altruistiske handlingar over tid ville føre til ei endring av menneskeætta.

Argumentasjonen for at det ikkje er nokon essensiell biologisk skilnad mellom dyr og menneske har mellom anna ført til at medisinske forskarar med truverde kan overføre resultat frå eksperiment utført på dyr til menneskelege tilhøve. Og i stor mon er slike analogislutningar uproblematiske når det gjeld studiar av fysiologiske tilhøve, som til dømes nyrefunksjon eller blodcelleproduksjon. Men ein lyt vere meir varsam når det gjeld eksperiment som involverer dei høgare mentale eigenskapane som finst hjå mennesket. Som peikt på av Hegel og 


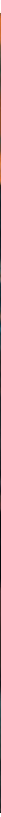

Figur 1 Paul Gauguin. Kvar kjem vi frå? Kva er vi? Kvar går vi? 1897. Lest frå høgre mot venstre viser biletet fødsel, liv og død; ei runde i livssyklusen. Foto akg-images/SCANPIX

fenomenologisk orienterte forskarar har mennesket ei unik evne til å kontekstualisere seg sjølv i ein situasjon (5). Tek ein ikkje omsyn til dette, kan ein fort konkludere feil. Fenomenet placebo er eit godt døme på kor viktig slik kontekstualisering er.

\section{Overskridande aktivitet}

Gjennom verket skaper kunstnaren ei eiga røynd. Resultatet er ikkje gjeve på førehand og kjem ofte uventa, endåtil på kunstnaren. Til dømes låg jazz, hiphop og rock som uforløyste uttrykk heilt frå den tida då mennesket byrja å skape musikk. Men fyrst i det 20. hundreåret vart dei realisert. Dei musikalske uttrykka vart ikkje skapte av eitt enkelt individ, men av mange, og ingen av bidragsytarane tenkte truleg på at dei skapte noko nytt der og då. Det er som om «fornufta si list» har hatt eit ord med i spelet.

Hegel søkte å klargjere strukturen som gjorde den menneskelege fornufta sine overskridingar mogleg, og denne fann han i den dialektiske logikken: Over tid vert ein tese møtt med ein antitese, som so i sin tur vert sameina med tesen og heva til ein syntese. Syntesen vert dermed ei overskriding av dei opphavlege tesane. Eit eksempel på slik aktivitet finn vi i vitskapen. Thomas Kuhn (1922-96) hevda at all vitskap går føre seg innanfor eit gjeve paradigme, det vil seie innanfor eit sett med premiss og metodar som vert sett på som ufråvikelege (6). Men etter kvart vil det kome fram observasjonar som viser at føresetnadane som forskarane har bygd på, er mangelfullt forstått. Då ligg det til rette for ein vitskapleg revolusjon med overskridande ny innsikt som resultat.

Darwins teori skapte ein slik vitskapleg revolusjon. Men det interessante med Dar- wins teori i denne samanhengen er at ikkje berre er teorien hans eit døme på at teoriar tilkjem som fylgje av ein overskridande aktivitet. På same måte er faktisk sjølve livet ein overskridande aktivitet. Slik omgrepa formar seg og får nytt innhald til ulike tider, slik tilkjem det nye livsformer etter kvart som tida går. I begge høve er det snakk om former som låg latente i dei føregåande formene, men som vanskeleg lét seg føreseie.

\section{Biologiske forklåringar}

Darwin var ein mistilpassa medisinarstudent, og etter to års mistrivnad gav han som 18-åring opp å studere sjukdomsprosessar (7). Han heldt fram med å studere livets ytringar, men då helst det veltilpassa og friske livet. Det er derfor kan hende ikkje så underleg at den teorien han utvikla ikkje har funne gode vekstvilkår i medisinen. Kva er føresetnadane for god helse? vil vere eit typisk evolusjonært spørsmål, medan Kva er føresetnadane for å utvikle sjukdom? vil vere eit typisk medisinsk spørsmål. Begge tilnærmingane jaktar på årsaker, men på ulikt vis.

Den nederlandske biologen Nikolaas Tinbergen (1907-88) klargjorde strukturen for vitskaplege årsaksforklåringar i biologien (8). Han hevda at når eit biologisk fenomen skal forklårast, lyt ein heilt generelt gje to typar forklåringar, ultimate og proksimate. Til dei ultimate forklåringane la han evolusjonær funksjon og fylogenese, medan han til dei proksimate forklåringane la årsak (fysiologi) og ontogenese.

Tinbergens kategorisering er òg nyttig når ein skal gje forklåringar på sjukdom, til dømes IgE-utløyst allergisk astma. Frå eit slikt perspektiv er sjukdomen forstått når ein veit kva i årsakskjedene som sviktar.
Men kan eit slikt biologiskinspirert mønster verkeleg gje heile forklåringa på astmatisk allergi? Korleis skal ein til dømes då forklåre at opplevd meistring/avmakt hjå pasientar med astma lettar/forverrar anfalla (9)?

Det finst etter kvart mykje god empiri som klårt viser at sentralnervesystemet, det endokrine systemet og immunsystemet gjensidig påverkar kvarandre til helse og uhelse (10), og det synest som at ein i det biologiske skjemaet har gløymt kor viktig det mentale opplevingsaspektet, det vil seie førstepersonsperspektivet, er. Og dette perspektivet kan ein ikkje fange utan å forstå korleis sinn og kropp er integrert $i$ ein kulturell kontekst.

\section{Medisinsk teori og praksis}

Medisin er ein praktisk retta disiplin som byggjer på eit vitskapleg grunnlag, noko ein i dag finn att som fyndorda «kunnskapsbasert praksis». Men mykje tyder på at teoriane innan medisinen ikkje alltid samsvarer med praksis, at det $\mathrm{i}$ det minste for nokre lidingar er eit mistilhøve mellom teoriane og det teoriane handlar om $(10,11)$. Det har også kome kritikk mot biomedisinaren for at han ikkje tek det sjuke mennesket sine opplevingar på alvor og endåtil berre ser fragment av det heile mennesket (12). Slike observasjonar og tolkingar tyder på ein anomali innanfor det biomedisinske paradigmet, eller sagt med ei hegelsk vending: at omgrepa ikkje er harmonisert med verda. Konsekvensen av slik mangelfull forståing ser ein att som auka implementering av teorifattige empiriskfunderte retningsliner.

Til tross for teoretisk underskot og mangel på kunnskapsbasert praksis, det vert gjort mykje godt arbeid på legekontora. 
At behandling forordna på mangelfullt teoretisk grunnlag kan lukkast, synest kontraintuitivt gjeve det rådande kunnskapssynet. For å gjere det heile litt meir intuitivt kan det derfor, innanfor paradigmet, ropast på meir empirisk forsking og fleire kunnskapsbaserte prosedyrar. Men meir av det same - det å arbeide vidare og meir intenst med den same kabalen, er neppe alltid beste løysinga. For når ein ikkje kjem vidare, kan det vere fordi kabalen ikkje går opp. Då veit einkvar at det å dele korta på nytt er einaste botemiddelet. Ei nydeling av korta vil i dette høvet kunne tillate kritikk av sjølve paradigmet, og det vil kunne reisast spørsmål om det ikkje er slik at praksis i mangt er kome lenger enn teorien, og at praktikaren endåtil sit på ein meir grunnleggjande kunnskapsbasert visse enn teoretikaren.

I medisinsk praksis, om enn ikkje i medisinsk teori, vert både evolusjonshistoria og åndshistoria heilt naturleg integrert med det enkelte individets biografiske historie. Når ein pasient kjem til konsultasjon, er det naturleg for klinikaren å hente fram ulike typar bakgrunnskunnskap. Kven pasienten ættar frå gjev viktig informasjon om arvelege disposisjonar. Kvar han vaks opp gjev informasjon om kulturelle tilhøve.

Pasienten si sjukehistorie kan avsløre viktige biografiske særtrekk som kan ha høg informasjonsverdi. Det at praktisk medisin tek opp i seg historisk kunnskap, er altså ikkje ukjent.

Det at praksis i mange høve fungerer på eit vis til tross for mangelfullt utvikla teori, peiker ut ei mogleg retning for teoriutviklinga: Ved å hente inn kunnskap frå fenomenologisk forsking vil teorien kunne ta vare på enkeltindividet $(10,13)$, og ved å ta opp innslag av ultimate biologiske forklåringar vil medisinen kunne forankrast trygt i biologien $(1,14)$.

\section{Frampeik}

I mange høve er det naudsynt å finne méd bakover i historia for å kunne peike ut retning framover. Hegel og Darwin kom begge med teoriar og perspektiv som bidrog til nettopp dette. Begge teoriane er vidareutvikla, men framleis har det ikkje kome i stand ein syntese mellom dei. Framleis er det $i$ teorien ein skilnad mellom mennesket som åndeleg og mennesket som biologisk vesen, mellom sinn og lekam, mellom somatikk og psykiatri. Denne oppspaltinga av mennesket gjer medisinen, om ikkje alltid medisinaren, kraftlaus i møtet med mange pasientgrupper. For å kome vidare lyt medisinen rykkje attende til sjølve mennesket. Derifrå kan medisinen, gjennom ein tostegs prosess støypt i ei klassisk hypotetisk-deduktiv form, generere nye teorivariantar og hypotesar som kan selekterast basert på kor godt dei høver med praksis.

Menneskeætta og medisinen står framfor store utfordringar dersom klimaet endar opp der prognosane peiker. Kan hende vert sjølve livsgrunnlaget for mennesket rasert. Nettopp for å møte ei slik utfordring, for å kunne gje gode svar på Gauguins tredje spørsmål Kvar går vi?, treng vi gode svar på det fyrste spørsmålet - Kvar kjem vi frå?

Oppgitte interessekonflikter: Ingen

\section{Litteratur}

1. Ulvestad E. Defending life. The nature of hostparasite relations. Dordrecht: Springer, 2007.

2. Hegel G. Phenomenology of spirit. Oxford: Oxford University Press, 1977.

3. Darwin C. The origin of species. London: Penguin Books, 1985

4. Darwin C. The descent of man. London: Gibson Square Books, 2003

5. Moran D. Introduction to phenomenology. London Routledge, 2000.

6. Kuhn T. The structure of scientific revolutions. Chicago, II: The University of Chicago Press, 1996.

7. Eldredge N. What Darwin learned in medical school. Lancet 2009; 373: 454-5.

8. Tinbergen N. On aims and methods in ethology. Z Tierpsychol 1963; 20: 410-33

9. Bloomberg GR, Chen E. The relationship of psychologic stress with childhood asthma. Immunol Allergy Clin North Am 2005; 25: 83-105.

10. Ulvestad E. Chronic fatigue syndrome defies the mind-body-schism of medicine. New perspectives on a multiple realisable developmental systems disorder. Med Health Care Philos 2008; 11: $285-92$

11. Hetlevik I, Getz L, Kirkengen AL. Allmennleger som ikke følger retningslinjer - kan de ha sine grunner? Tidsskr Nor Legeforen 2008; 128: 2218-20.

12. Getz L. Fragmentenes forvaltere. Tidsskr Nor Lægeforen 2001; 121: 1562.

13. Kirkengen AL, Getz L, Hetlevik I. En annen kardiovaskulær epidemiologi. Tidsskr Nor Legeforen 2008; 128: 2181-4.

14. Kirkengen AL, Ulvestad E. Overlast og kompleks sykdom - et integrert perspektiv. Tidsskr Nor Lægeforen 2007; 127: 3228-31.

Manuskriptet ble mottatt 17.7. 2009 og godkjent

5.11. 2009. Medisinsk redaktør Erlend Hem. 